\title{
Increasing potential risk for American visceral leishmaniasis in Amapá, Brazil
}

\author{
Thiago Vasconcelos dos Santos ${ }^{[1]}$, Allan Kardec Ribeiro Galardo ${ }^{[2]}$, \\ Marinete Marins Póvoa ${ }^{[1]}$ and Elizabeth Ferreira Rangel ${ }^{[3]}$
}

\begin{abstract}
[1]. Instituto Evandro Chagas, Secretaria de Vigilância em Saúde, Ministério da Saúde, Ananindeua, Pará, Brasil. [2]. Instituto de Pesquisas Cientificas e Tecnológicas do Estado do Amapá, Macapá, Amapá, Brasil.

[3]. Laboratório Interdisciplinar de Vigilância Entomológica em Diptera e Hemiptera, Instituto Oswaldo Cruz, Fundação Oswaldo Cruz, Rio de Janeiro, Rio de Janeiro, Brasil.
\end{abstract}

\begin{abstract}
Introduction: The present note discusses some evidence on the increasing potential risk for American visceral leishmaniasis (AVL) transmission in the Northern Brazilian State of Amapá, the Guianan-Amazon biome. Methods: Early and present data about AVL were collected, including our recent entomological findings. Results: The spread of the sand fly vector Lutzomyia longipalpis, and a sylvatic reservoir host, the crab-eating fox Cerdocyon thous in that region represents important findings related to the epidemiology of AVL in the Guianan-Amazon biome. Conclusions: These observations suggest that Brazilian authorities need to develop surveillance strategies in these risk areas.
\end{abstract}

Keywords: American visceral leishmaniasis. Epidemiology. Risk.

American visceral leishmaniasis (AVL) is considered a zoonotic disease caused by Leishmania (Leishmania) infantum chagasi. It is distributed in the Americas, including some large emerging foci in the Brazilian Amazon region; in Brazil, it has been recorded in most states with different geographical regions $^{(1)(2)(3)}$.

The Guianan Ecoregion Complex (GEC) comprises particular ecologic areas from the Guiana Shield within the Amazon biome, which covers Western Venezuela, Northern Brazil, Guyana, Suriname, and French Guiana. In the GEC, cases of autochthonous AVL have been registered, mainly in Venezuela and Brazil (the Northern Pará and Roraima States) where there have also been official reports about the vector Lutzomyia longipalpis. Doubtful sporadic AVL occurrence in Suriname and the absence of vector information in AVL focus of Guyana has drawn attention for the need to further investigate these areas ${ }^{(4)}$.

On the basis of this epidemiological background, we present communication aimed to discuss early and current data about the occurrence of the AVL sand fly vector and reservoir host in Amapá, Brazil, to highlight this importance for the ecology of AVL in the Brazilian Guianan-Amazon biome, and to draw attention to Brazilian and international public health issues.

Corresponding author: Dr. Thiago Vasconcelos dos Santos.

e-mail: thiagovasconcelos@iec.pa.gov.br

Received 28 July 2016

Accepted 8 September 2016
Since the 1950s when the first clinical-entomological survey on American cutaneous leishmaniasis (ACL) was conducted in Amapá( ${ }^{(5)}(6)$, few studies have been published about sand fly fauna, and until recently, only vectors of ACL have been found ${ }^{(7)}$. The first occurrence of L. longipalpis, however, was reported in 2013 during activities of a vector monitoring program for a hydroelectric system placed in the municipality of Ferreira Gomes; specimens were captured in a rural environment closely associated with peri domiciliar areas with dog shelters ${ }^{(8)}$. In subsequent captures, including a recent one made during November 2015, this sand fly species still seemed to be very frequent in the same environments. It can be speculated that the lack of entomological investigations in other municipalities eco-geographically close to Ferreira Gomes may be bias to the underreporting of the distribution of L. longipalpis in Amapá. Moreover, L. longipalpis was found to be associated with chicken shelters in the municipality of Almeirim (Pará) near from the municipality of Laranjal do Jari (Amapá) (AKR Galardo: personal observation). This latter region has only been associated with the epidemiology of $\mathrm{ACL}^{(9)}$. However, it is important to note areas that have been recently investigated, including some areas in Amapá: Serra do Navio, Laranjal do Jari (a hydroelectric system impacted area), Ferreira Gomes [FLOresta NAcional (FLONA) do Amapá; (National Forest of Amapá)] and Oiapoque where until now, L. longipalpis is apparently absent (AKR Galardo and TV Santos: unpublished observations). These surveys will be a subject of future publications from our group. 
The natural reservoir of Leishmania (Leishmania) infantum chagasi, the crab-eating fox Cerdocyon thous, was unknown to be present in Amapá, despite its known widespread presence in South America. However, the distribution of this mammal has been updated since it has been found in savannas near the municipalities of Ferreira Gomes and Porto Grande (Matapi River) and in the terra-firme forest near the Macapá municipality (environmental protected area - APA Curiaú) ${ }^{10)}$. Later, a cameratrap study conducted in Cabo Orange National Park registered this species in the savannas near Cassiporé River (Calçoene municipality) ${ }^{(11)}$.

Considering the vector-reservoir information, it must be highlighted that these data may represent an increasing risk of the establishment of the AVL transmission cycle in Amapá. In a closely geographically related territory of French Guiana, a canine case of visceral leishmaniasis was reported as imported from the Old World. Interestingly, a supposed sexual transmission to a native dog has been proven, as this fact was considered based on sustaining the hypothesis of intercontinental dispersion of this parasite (assumed as L. infantum); however, until now, no autochthonous cases have been documented since the vector L. longipalpis is still absent from that territory ${ }^{(12)}$.

Nevertheless, the close relationship between Amapá and French Guiana because of human activities may probably act as a bridge for vector dispersion. In Brazil, the geographic spread of AVL is historically recognized ${ }^{(13)}$, and different transmission profiles may be emerging in strategic areas such as the international borders ${ }^{(14)}$. Further studies on populations of $L$. longipalpis from these emerging foci could improve the understanding of the origins of putative vector dispersion in the Guianan-Amazon leishmaniasis region.

The recommended epidemiological surveillance of the Programa de Vigilância e Controle da Leishmaniose Visceral (Visceral Leishmaniasis Surveillance and Control Program) by the Ministry of Health in Brazil plans to incorporate silent areas (without records of human and/or canine cases of AVL) for surveillance actions to avoid or minimize possible impacts of the disease in new areas ${ }^{(14)}$. Thus, regarding Amapá, a further canine survey in areas with the occurrence of L. longipalpis is an important step to continuing the entomological survey.

\section{Acknowledgments \\ We thank the Instituto de Pesquisas Cientificas e Tecnológicas do Estado do Amapá entomology team and the Ferreira Gomes Geração de Energia staff for providing technical and financial support, respectively.}

\section{Conflict of Interest}

The authors declare no conflict of interest concerning this manuscript.

\section{Financial Support}

Financial support was received from Ferreira Gomes Geração de Energia and the Instituto de Pesquisas Científicas e Tecnológicas do Estado do Amapá.

\section{REFERENCES}

1. Lainson R, Shaw JJ, Ryan L, Ribeiro RSM, Silveira FT. Leishmaniasis in Brazil XXI: visceral leishmaniasis in the Amazon region and further observations on the role of Lutzomyia longipalpis (Lutz \& Neiva, 1912) as the vector. Trans Roy Soc Trop Med Hyg $1985 ; 79: 223-226$.

2. Lainson R, Rangel EF. Lutzomyia longipalpis and the ecoepidemiology of American visceral leishmaniasis, with particular reference to Brazil: a review. Mem Inst Oswaldo Cruz 2005; 100:811-827.

3. Vilela ML, Afonso MMS, Costa SM, Costa WA, Rangel RF. Lutzomyia (Lutzomyia) longipalpis: fatores associados ao processo de expansão e urbanização da leishmaniose visceral americana. In: Conceição-Silva F, Alves CR organizadores. Leishmanioses do Continente Americano.

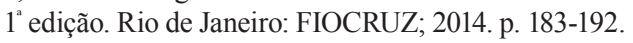

4. Rotureau B. Ecology of the Leishmania species in the Guianan ecoregion complex. Am J Trop Med Hyg 2006; 74:81-96.

5. Forattini OP, Juarez E, Bernardi L, Dauer C. Leishmaniose tegumentar, no território do Amapá, Brasil. Rev Inst Med Trop São Paulo 1959; 1:11-17.

6. Forattini OP. Sobre os flebótomos do território do Amapá, Brasil. Arq Fac Hig Saude Publica Univ Sao Paulo 1959; 13:158-164.

7. Aguiar GM, Medeiros WM. Distribuição regional de habitats das espécies de flebotomíneos do Brasil. In: Rangel EF, Lainson R, editors. Flebotomíneos do Brasil. Rio de Janeiro: FIOCRUZ; 2003. p. 207-255.

8. Galardo AKR, Galardo CD, Santana AA, Mendes JCC, Souza FRA, Duarte JP, et al. Primeira ocorrência de Lutzomyia (Lutzomyia) longipalpis Lutz \& Neiva, 1912 (Diptera: Psychodidae: Phlebotominae) no Estado do Amapá, Brasil. Biota Amazon 2013; 3:179-183.

9. Ryan L, Lainson R, Shaw JJ, Braga RR, Ishikawa EA. Leishmaniasis in Brazil. XXV. Sandfly vectors of Leishmania in Pará State, Brazil. Med Vet Entomol 1987; 1:383-395.

10. Silva CR, Martins ACM, Castro IJ, Bernard E, Cardoso EM, Lima DS, et al. Mammals of Amapá State, Eastern Brazilian Amazonia: a revised taxonomic list with comments on species distributions. Mammalia 2013; 77:409-424.

11. De Thoisy B, Vergara M, Silvestro P, Vasconcelos I. Northern extension of records of the crab-eating fox in Brazil. Canid Biol Conserv 2013; 16:1-3.

12. Rotureau B, Ravel C, Aznar C, Carme B, Dedet JP. First report of Leishmania infantum in French Guiana: canine visceral leishmaniasis imported from the Old World. J Clin Microbiol 2006; 44:1120-1222.

13. Werneck GL. Expansão geográfica da leishmaniose visceral no Brasil. Cad Saude Publica 2010; 26:644-645.

14. Ministério da Saúde. Secretaria de Vigilância em Saúde. Departamento de Vigilância Epidemiológica. Manual de Vigilância e Controle da Leishmaniose Visceral. $1^{\mathrm{a}}$ edição. Brasília: Ministério da Saúde; 2014. 